\title{
INVESTMENTS IN THE DEVELOPMENT OF INNOVATIVE MANAGEMENT IN THE COMPANY
}

\author{
Natalia Germanjuk ${ }^{1}$
}

\begin{abstract}
The subject of research. This article determines that in conditions of global transformational processes, the sphere of innovation activity becomes of particular importance in the economy of advanced countries. Its development provides socio-economic growth of local companies and a state, in general, requiring significant financial resources. Consequently, the subject of this study is the management of innovation activities at the enterprise with the achievement of maximum effectiveness, as well as the identification of interconnection between innovations and investments. Methodology. Conducted research shows, the condition of development of domestic technologies is unsatisfactory: Ukraine occupies the last place among European countries. Innovative activity is associated with investments, whose government support in our country is rather small in the context of the state's GDP. Content analysis is carried out on materials of works of domestic and foreign scientists using information from Ukrainian legislation and statistical data provided by experts. In the process of preparing the paper, the following general scientific methods of research are used: logical analysis, observation, formalization, synthesis, abstraction. The purpose of a study is to analyse the nature of the innovation activity of companies, to establish its unbiased relationship with investment processes in order to identify areas for improving the innovation and investment situation in Ukraine. Important is to substantiate the expediency of improving the innovative management of Ukrainian enterprises in the focus of implementation of new projects by finding the necessary sources of financing. As a result - effective management of the company is capable of satisfying consumer demands and increase profits. Conclusions. Thus, the analysis of the relationship between innovations and investments has shown that the situation in Ukraine is characterized by a deficit of state support in the investment and innovation sector, and difficulties in attracting finance. The latter is directly related to the political situation, instability, the lack of clear legislative rules of direct action, as well as insignificant pay for the work of inventors. At the same time, the positive direction of innovation development in Ukraine is the tendency to increase venture companies (with the use of foreign experience), which directly provides investment in the latest local finds. Improving the investment and innovation situation in Ukraine is possible by creating a set of incentives for attracting investment, further investing in human capital, raising wages for researchers; growth of inflow of foreign investments; providing tangible state support to enterprises and more favourable lending conditions for them, etc. It is important to ensure transparency of legislation, to perfect the conditions of functioning of business space and the state of market infrastructure, to take measures to improve the state of the environment.
\end{abstract}

Key words: investment, innovation, innovative management, competitiveness, venture fund.

JEL Classification: G0, O3, M1

\section{Introduction}

Today in the transformative conditions of functioning ofmarketspace, the conceptofaninnovativemanagement occupies the main role in the management of any company that is directly related to the determination of competitiveness level. Innovative management is a certain coordination-economic method and the directions of control of all stages and types of innovative processes at the enterprise with maximal effectiveness. The latter is a part of the investment management studying the mechanisms of investing recourses in the

Corresponding author:

${ }^{1}$ Vinnytsia National Agrarian University, Ukraine.

E-mail: natagermanjuk@gmail.com development of the innovation sphere, the expediency of their direction and profitability.

As we know, the main objective of modern management is to provide the most effective ways to apply the innovative strategy in the company at certain stages of development. In the realization process of this, the management mechanisms orients to solve the following essential tasks: the guarantee of high temps of enterprise increase and its competitiveness; maximization of profits thanks to effective innovative activity; minimization of risks during the financing of 
progressive projects; maintaining the business stability and solvency while the embodiment of new processes; search for ways to accelerate the creation of innovative projects.

Modern scientific findings tell about the most effective capital investment is the new products financing: the enterprise can get super profits from a successful innovative launch. A great potential for progressive operations provides the consumer demand and forms the market of scientific-technological, socio-economic innovations.

The urgency of research in any economic sector needs to the calculated capital investments with the purpose of getting socio-economic effects, extra profit and growth of competitiveness of a company. Herewith the certain regularity observes: the higher revenue is expected to get, the more costs are necessary to innovation at the incarnation stage.

\section{Literature review}

Considerable amount of works of well-known foreign economists, particularly J. Schumpeter (1982), B. Twiss (1989), B. Santo (1990), M. Huchek (1992), P. Drucker (2007), J. Stirling (2011), B. Brown (2015), and others is devoted to theoretical issues of the development of innovation and investment environment, the identification of ways to attract financial resources for the implementation of the latest developments, also of the need of enterprise management in the direction of the introduction of modern finds.

The purpose of the research of many Ukrainian scientists is to study the following significant issues: assessment of the investment appeal of companies and the feasibility of attracting investments for the aim of implementation of innovative projects - Z. Lytvyn (2014); influence of innovations and investments on strategic activity of enterprises, identification of development factors that should be taken into account during the formation of innovation-investment state policy - I. Andryushchenko (2014); management of investments and innovations in the company, monitoring of demand for progressive developments, their effectiveness - O. Skibitsky (2009); definition of priority guidelines for improving innovation and investment activity in the current transformed conditions - S. Usherenko (2014); analysis of the main directions, potential opportunities, and threats of progressive development of Ukraine - M. Sokach (2016); modelling of innovative entrepreneurship, cooperation of science with production and universities O. Tkachuk (2016); system of international indicators for assessing the country's resources and possibilities for realizing the potential of Ukraine in order to accelerate the innovative development - O. Levkovsky (2017), etc. Such problems, we think, require further discussion: the prospects of development of Ukrainian innovation space, with emphasis on the importance of more active search and attraction of investments by domestic companies in high-tech finds.

\section{Goals and tasks of the article}

Innovative sphere of the enterprise is tightly interconnected with investments: the realization of innovations provides for the definitions of sources of their financing - the part of attracted funds gears towards progressive operations that require the deepest researches.

The purpose of the article is to analyse the nature of the innovation activity of companies, to establish its unbiased relationship with investment processes in order to identify areas for improvement of the innovation and investment situation in Ukraine. In our opinion, it is possible, first of all, due to the concentration of financial investments in the priority sectors of innovation development in the regions through the use of quality management, which will contribute to the economic growth of the state. Clarification of this fact is the main task of our research.

\section{The main material of research}

The investment policy of the enterprise is a set of tactical management solutions that address the ways of attracting and spending funds for the target of investing. The main strategic types are classified according to the place of resources receipt and direction of investment activity. Criteria for the attractiveness of finding resources are the reality of their using, potential capacity, economic effectiveness, and level of application risk. The own means of company differ the biggest availability, which orients the administration at their effective using and they have the low-level the loss of control for assets. Engagement of credit resources also contributes to the innovative projects' implementation, but it has a low reach degree.

Elements of the attractiveness of innovative projects for investors are divided into financial-economic and non-economic. As a rule, depositors are interested in the possibility of obtaining of high incomes, but sometimes invest money in the realization of a new product without getting of direct economic profit. So, this applies to experimental medical projects, progressive ecological measures that most often have the negative financial results. Usually, enterprises are active in this direction in order to maintain their own image. In making decisions concerning financing innovative projects, the investors need to know the period during which the funds will be returned and terms of receiving the calculated profit (Porshnev, 2016).

Achievements of essential competitive advantages and innovative result depend on balancing between purpose, tasks, and scopes of financial investments. 
The investment process is a long-term capital engagement, which uses with aim of development, expansion of production and getting of incomes. The main sign of new products is a scientific and technical novelty and productive application. Any successful company operates in conditions of own constructive activity - uninterrupted process, which orients at the creation of the new product that can satisfy progressive social or individual needs.

The ultimate result of innovation management is the realization of advanced discovery and mastery of the production process. Stimulus to create the innovative projects can be as scientific-technical development, so marketing researches in a direction of the detection of dissatisfied consumer needs. The main criteria for choosing innovations are presented below (Table 1).

On the basis of scientific researches, it is established that beginning of investment in innovative management of the company may be the next sequence of actions:

- choice of investment policy;

- monitoring of investment objects;

- creating a portfolio of objects;

- evaluating the rationality each of the proposed objects; - determination of the effectiveness of the project, analysis of innovation portfolio.

In whole, management of innovative process in the company has four stages:

1) conducting fundamental research and obtaining an invention;

2) applied studies;

3) experimental projects;

4) commercialization of technological innovation, its full use.

It is clear that, in order to survive in today's competitive conditions, an enterprise must constantly introduce progressive innovations into its own business. Innovative activity is an important requisition of socio-economic development oriented, first of all, at the increase in competitiveness products, which are proffered. The concept of competitiveness includes the characteristic of goods that distinguishes them from a competitor's analogues concerning the level of compliance with certain needs and costs of their satisfaction. The main details of goods competitiveness are the consumer signs and price. Such factors as advertising, the image of the enterprise, service level also play a significant role.

The effective management of a company towards increasing the degree of product competitiveness ensures the optimal balance of its elements - growth of goods quality, reduction of production costs, and improvement of service level. Each of these items can be considered like a complex separate object of management. In particular, the price, quality of raw and electricity, the workers' qualification, the salary of staff and administrative expenses affect the costs volume. At one time, all components are determined by the technical level of production, the construction of manufacturing process and management.

We note the USA among world countries allocates the largest means to innovative research and development. According to the rating data of the Global Competitiveness Index, every year the state spends 405 billion dollars on science (to $2.7 \%$ of GDP). China takes the second place, in which the financial researching volumes make up 338 billion dollars a year (2.1\% of GDP), the third - Japan, 160 billion dollars. For comparison: on the support of innovations, Ukraine spends from the budget 16 billion UAH per year $-0.8 \%$ of GDP (Forbes, 2016).

The base of the company's prosperity, as we think, is a subordination of interests to goals of designing, manufacturing, and marketing of competitive products with an emphasis on long-term success and consumer needs. Herewith the income from the implementation of the innovative product during lasting time can be absent and the resources are only consumed. After that the innovation is rapidly spreading, providing a return on investment in it at least fifty times. Otherwise, the project is considered unsuccessful. Companies focus their activities on the development and introduction of new products in the presence of potential types of risk (Table 2), as well as, separately, of their additional type - innovation risk.

Table 1

Selection criteria for innovations

\begin{tabular}{|c|c|}
\hline Selection criteria & Essence \\
\hline $\begin{array}{l}\text { Compliance with } \\
\text { goals of company }\end{array}$ & image of the enterprise; acceptable level of risk; planned implementation time \\
\hline Market & $\begin{array}{l}\text { probable need for a product; the possibility of commercial success; expected sales volume; cost/product cost ratio; } \\
\text { initial expenses and sources of their receipt; competition strategy; necessary sales channels }\end{array}$ \\
\hline $\begin{array}{l}\text { Scientific and } \\
\text { technical }\end{array}$ & $\begin{array}{l}\text { compliance with general sales strategy; the probability of technical success; costs and terms of project; patent } \\
\text { purity; availability of scientific and technical resources; prospects for scientific and technological development }\end{array}$ \\
\hline Financial & movement of costs and incomes in time; influence at other products \\
\hline Productive & production capacity; production costs; safety of production; the need for cooperation \\
\hline Ecological & $\begin{array}{l}\text { structure and amount of energy resources used; structure and amount of emissions; utilization conditions } \\
\text { of products }\end{array}$ \\
\hline
\end{tabular}

Source: (Goller, 2017) 
Table 2

Classification of potential risk in business activity

\begin{tabular}{|l|c|}
\hline \multicolumn{1}{|c|}{ Type of risk } & Part, \% \\
\hline systematic financial risks & 100 \\
\hline operation risk & 89.6 \\
\hline credit risk & 14.3 \\
\hline information risk & 9.1 \\
\hline personnel risk & 3.9 \\
\hline cheating business partners & 1.2 \\
\hline
\end{tabular}

Source: (Official site Forbes, 2017)

Innovation risk represents the probability of losses when investing funds in new technology, a complete guarantee of expected demand for which is practically absent. The most inherent today are such its varieties: implementation of a mistakenly selected project; lack of agreement between partners; marketing risk associated with supply and sales conditions. Business leaders of enterprise, first of all, must learn to effectively manage innovation risks in order to avoid possible negative performance.

It is advisable to manage the innovation processes of company activity in such a way the personnel perceived the implementation of progressive developments into production as a favourable opportunity and expected profit in near time. So, innovations are the employment and well-being of every worker at the enterprise.

The important prerequisite of innovative policy serves moral aging of manufactured products or technologies. To prevent the latter, it is advisable to check timely the goods and equipment, which are produced, working conditions analysing the market and sales channels.

One of the main indicators of the development level of innovative activity in the state is material support of scientific workers that is an important factor constraining the "brain drain". So, according to The New York Times, researchers are most appreciated in Canada, the USA, Italy, the United Kingdom, and Saudi Arabia where their monthly salary is on average equal to $\$ 5000-\$ 9000$. In recent years, revenues of scientists in India have risen markedly, exceeding the $\$ 7000$. In China, where a few years ago scientists received about $\$ 250-\$ 300$, the government has increased salaries in times as the development of science and education is the part of a national program of economic growth.

In Ukraine, according to data of International foundation for research in educational policy and State Statistics Service, the average monthly salary of teachers and scientists ranges between $\$ 100-\$ 300$, which leads to negative consequences: by various estimates, from 6000 until 9000 representatives of intellectual professions are leaving our country every year. At the same time, the age of $80-85 \%$ scientific staff is approaching the retirement (Forbes, 2016).

Recently it takes place the appearance of state programs, which declare the transition of Ukraine at the innovative direction of social economic development with government support providing. It is also considered the project of innovative codex and creation of a national venture company. The use of progressive research of neighbouring countries by domestic scientists is growing, but the noticeable shifts are absent in the innovative development of the state.

Relative to the EU countries, the minimal indexes of innovative activity are in Portugal $-26 \%$, Greece $29 \%$ and even they improve the Ukrainian indicators. Compared with the leading states such as Netherlands (62\%), Austria (67\%), Germany (69\%), Denmark (71\%), and Ireland (74\%), our country lags almost at five times - for the resolution of the Verkhovna Rada of Ukraine (2017).

Today, a special system of investing in new projects and one of the main mechanisms for the growth of many foreign enterprises is venture capital investment. Among such companies, there are DEC, Apple, Compaq, Sun, Microsoft, Intel, Silicon Graphics, Google, Skype. Venture capital is used by the countries of the EU, Taiwan, China, Israel, and so on. More than 600 appropriate funds registered in Ukraine, from which function a little over 100. The spheres of their activity, as a rule, are building and energy resources trade. Some venture funds engaged in the financing of other traditional projects or not large food innovations (UAIB, 2017). The indicators of such institutions show the absence of special incentives and warranty to invest the resources in innovative domestic projects in connection with the presence of a high-risk level. Today the primary function of Ukrainian venture funds is the "instrumental" one, which legislatively contributes to the improvement of taxation processes in Ukraine.

About the financing of Ukrainian innovative projects, we need to note the presence of essential potential for the attraction of investments observes in the Kyiv region. It is about the creating of industrial parks, production modernization, development of agricultural sphere, alternative power engineering, aviation branch, and tourism. At most, modern investors interest in the innovative improvement of the agrarian and production sectors in this area. Regional administration engages in the prosperity of local tourism in order to build the competitive service market, according to the results of the Forum (2015). All these can serve the practical guide in direction of innovative activity growth of enterprises in other Ukrainian regions.

\section{Conclusions and recommendations for the further research}

Thus, an analysis of the relationship between innovation and investment has shown, there are indispensable state support and supportive market environment for the development of the innovation sector in countries such as the USA, China, Japan, the 
Netherlands, Austria, etc. In turn, most appreciated are the researchers in Canada, the USA, Italy, Great Britain, Saudi Arabia, South Africa, as evidenced, above all, by high wages and the creation of appropriate conditions for creative innovative search. The listed contributes to the progressive development of companies, provides their competitiveness on the world market and the growth of the state's economy as a whole.

Regarding Ukraine, noticeable shifts in this direction, unfortunately, are not observed. The situation is characterized by a deficit of government support in the investment and innovation sector, difficulties in attracting of finance. The latter is directly related to the political situation, socio-economic transformation processes, instability, the lack of clear legislative rules of direct action, as well as the insignificant pay of the work of inventors, which causes "brain drain" from our country.

Discovered, at the enterprise, in the process of innovation activity, there is an additional type of risk - an innovative one that does not provide full guarantees of the demand of a particular innovation, which may result in totally unjustified investments in development and implementation of high-tech projects. The important direction in order to prevent the last, as we believe, is a thought-out decision making on the implementation of the latest product based on the perfect monitoring of market demand of consumers, the availability of business talent and work experience with successful innovative products at managers.

In addition, the positive direction of Ukrainian innovation development is a tendency to increase venture companies (with using of foreign experience) that directly provides investment in the latest local finds. However, indicators of these institutions activity testify, there are no special incentives and guarantees to invest in such projects - in the presence of a high-risk degree. In fact, the main attribute of Ukrainian venture funds is the legitimate promotion of taxation processes improving.

It has been revealed that Kyiv region has a significant potential for attracting investments in future innovations, in particular, it is about the modernization of industrial facilities, development of the agrarian sector and alternative energy, aviation industry, tourism, etc.

As we see, it is possible to improve the investment and innovation situation in Ukraine due to the concentration of financial investments in the priority areas of innovation development in the cut of regions through the use of effective management, which will contribute to the economic growth of our state. Necessary is the creation of a complex of incentives for attracting of investments, further investing in human capital, increasing salary for researchers, which can provide accelerated implementation of modern technologies at domestic enterprises; growth of the inflow of foreign investments; providing tangible government support to companies (government procurement, tax breaks, simplification of licensing procedures, financing) and more favourable lending conditions. There are important: ensuring transparency of legislation, improving the conditions of the business space functioning and the state of market infrastructure, the realization of measures for the betterment of the environment.

\section{References:}

Vriatuvaty maibutnie: pershyi reitynh innovatsiinykh kompanii Ukrainy [Save the Future: The first rating of innovation companies in Ukraine]. Retrieved from: http://forbes.net.ua/ua/magazine/forbes/1416757vryatuvati-majbutne-pershij-rejting-innovacijnih-kompanij-ukrayini

Zakon Ukrainy «Pro investytsiinu diialnist» № 1560-12 vid 23.07.2017 [Law of Ukraine "On Investment Activity" № 1560-12 from 23.07.2017]. Retrieved from: http://zakon2.rada.gov.ua/ laws/show/1560-12

Zakon Ukrainy «Pro innovatsiinu diialnist» № 40-15 vid 05.12.2012 [Law of Ukraine "On Investment Activity" from 05.12.2012]. Retrieved from: http://zakon2.rada.gov.ua/ laws/show/40-15

Investytsii ta innovatsii u Kyivskii oblasti: rezultaty forumu [Investments and innovations in Kyiv region: results of the forum]. Retrieved from: http://platforma-msb.org/investytsiyi-ta-innovatsiyi-u-kyyivskij-o-3/.

Ofitsiinyi sait Ukrainskoi Asotsiatsii Innovatsiinoho biznesu [Official site of the Ukrainian Association of Innovation Business]. Retrieved from: http://www.uaib.com.ua

Porshnev, A. H., Azoev, H. L., Barancheev, V. P., Rumiantseva, Z. P., Salomatyn, N. A. (2016). Upravlenie orhanizatsyei [Management of the organization]. M.: YNFRA-M, 736 p.

Pro Rekomendatsii parlamentskykh slukhan na temu: «Stratehiia innovatsiinoho rozvytku Ukrainy na 2010-2020 roky v umovakh hlobalizatsiinykh vyklykiv»: Postanova VR Ukrainy. Vidomosti Verkhovnoi Rady Ukrainy [About the Recommendations of the Parliamentary Hearings on the theme: "Strategy of Innovation Development of Ukraine for 2010-2020 in the context of globalization challenges": Resolution of the Verkhovna Rada of Ukraine // Bulletin of the Verkhovna Rada of Ukraine]. Retrieved from: http://zakon2. rada.gov.ua/laws/ show/2632-17

Brockhoff, K. (2017). The emergence of technology and innovation management. Technology \& Innovations, no. 19(2), pp. 461-480.

Goller, I. (2017). Creativity for innovation management. New York: Routledge, 332 p.

Klingebiel, R., Rammer, C. (2014). Resource allocation strategy for innovation portfolio management. Strategic Management Journal, no. 35(2), pp. 246-268. 
Linder, M., Swedish, V. (2017). Circular business model innovation: inherent uncertainties. Business strategy and the environment, no. 26(2), pp. 182-196.

Pantano, E., Priporas, C.-V., Sorace, S., Iazzolino, G. (2017). Does innovation-orientation lead to retail industry growth? Empirical evidence from patent analysis. Journal of Retailing and Consumer Services, no. 34, pp. 88-94.

Sytnyk, H. (2017). Preliminary assessment of implementing the economic part of the National Security Strategy of Ukraine. Problems and Perspectives in Management, no. 15(4), pp. 24-37.

Tidd, J., Thuriaux-Aleman, B. (2016). Innovation management practices: cross-sectorial adoption, variation, and effectiveness. $R$ and \& Management, no. 46(S3), pp. 1024-1043.

Wieland, H., Hartmann, N. N., Vargo, S. L. (2017). Business models as service strategy. Journal of the Academy of Marketing Science, no. 45(6), pp. 925-943.

Zhang, J., Tan, J., Wong, P. K. (2015). When does investment in political ties improve firm performance? The contingent effect of innovation activities. Asia Pacific Journal of Management, no. 32(2), pp. 363-387. 